\title{
Arabised Terms in the Holy Quran Facts or Fiction: History and Criticism
}

\author{
Basma Odeh Salman Al-Rawashdeh ${ }^{1}$ \\ ${ }^{1}$ Al-Balqa Applied University, Princess Rahmah University College, Jordan \\ Correspondence: Basma Odeh Salman Al-Rawashdeh, Al-Balqa Applied University, Princess Rahmah \\ University College, Jordan. E-mail: dr.basmarawashdeh@yahoo.com
}

Received: January 13, 2014 Accepted: March 4, 2014 Online Published: August 29, 2014

doi:10.5539/ells.v4n3p90 URL: http://dx.doi.org/10.5539/ells.v4n3p90

\begin{abstract}
Nowadays, to tackle a subject fifteen hundred years old is not an easy task. Especially people are looking for simple and interesting issues. However, when it comes to faith, even if its vocabulary hard to understood, its subject must be interesting and attractive one. Thus, current study discusses an important issue that is, the alleged presence of foreign words in the Quran, while Quran declares the opposite of that.

This issue has kept philologists and scholars from so long until today discussing, debating and arguing its core elements.

Some supported the Quran point of view; other opposed while assuring the presence of foreign words in the Quran, while the third group takes the middle road between the two extremes.

Relying on numerous and trust worthy publications such as author Ibn Faris and other evidence, present author could prove that the Quran is entirely free from foreign terms.
\end{abstract}

Keywords: Quran, Arabised, foreign terms, Ibn Faris, supporters, denying, intermediate group

\section{Introduction}

The presence ofArabised terms in the Quran has kept our philologists, linguists and scholars with their varied ranks, places and times, busy in discussing, debating and arguing its core elements. Arabised terms in the Quran have been the core subject for their discussion therefore; some of them supported the Arabization existence in the Quran, while others denied it all, a third party has taken the middle position between the two extremes making a new moderate and satisfying doctrine, this approach or doctrine claims that terms origin is foreign, because our ancestors the original Arabs had Arabised and modified such terms; therefore, when Quran was revealed, it mentioned these terms the way our ancestors did, thus, the terms are of foreign origin however Arabic use.

Researcher prefers to have the book (Al-Sahiby in language philology and Arab approaches in speaking) by Ibn Fares (Albakhirzi, 1971) the historical source for this issue and the starting point in discussing and criticizing it is due to the following reasons:

i: Al-Sahiby book deals with set of linguistic issues, which it explains them logically and scientifically.

ii: The many linguistic issues which Ibn Farisprovided, didn't receive the serious study which show its scientific value, due for being brief in the book and are in need for more explanations and details.

iii: Ibn Faris was one of the fourth century's (Hijri) these scientists, thus, history means a long period of time from the day of Quran was revealed to the appearance of this issue. Al-Sahiby is conceded to be a historical document for the appearance of this problem and its development first; it is for the rise of this problem and is a picture reflects the change extend which happened on this issue and the transformation that took place among fourth century (Hijri) scholars and philologists.

iv: Ibn Faris is the Imam (pioneer) of the contrastive linguistics in the fourth hijri century, he is also one of the scientists who mastered multiple sciences, and were master in its creative ways especially Arabic language.

"Furthermore, whenever he met a philologist, articulate or grammarian he was ordering his companions to ask them about and debate such people in matter of sciences such philologist, articulate or grammarian was master that, he was winning over them." (Alzarkali, 1990b) 
No one then indicated to the year in which Ibn Faris was born except IbnFarhoon in the DebajAl-Muthahab (Al-Jawaleeqy, 1996) who said that Ibn Faris was born in the year of $306(\mathrm{H})$ or $308(\mathrm{H})$ which is acceptable to me. However, HelalNaji (Ibn Faris, 1963) claim that the year in which Ibn Faris was born 312 (H), and Alzarkali (Alqifty) $329(\mathrm{H})$ both are worthless claims. Similarly, the year of Ibn Faris died was disagreed upon by scholars, the acceptable claim be me is that the year in which Ibn Faris died was Safar of $395(\mathrm{H})$ in Rai. He was buried in it cross from chief judge's tomb, Abu AlHassan ben Ali ben Abdlazeez Al-Jerjani(IbnFarhoon.1329H) this because I found in the conclusion of the book (TamamFaseehAl-Kalam) a statement supports my argument that was written by Ahmad ben Faris ben Zakaria himself on Ramadan 393 (H) (Ibn Faris, 1963)

Ibn Faris left us a cultureal-heritage, the thing that distinguishes him from other. So he compiled vocabulary linguistic dictionaries. Moreover, he is considered to be the owner of total language (Al-Mojmal) according to Al-Bakherzi: "When language is mentioned, then Ibn Faris is the owner of total language, rather he is language owner who detailed it". (Yaqoot Alhamwy, 1993)

In addition to the dictionaries, he compiled (Al-Maqayees) the linguistic book along with being lexicographic book.

In regard to vocabulary dictionaries, in the dictionary meanings Ibn Faris left us:

(Motakhayer Al-Alfad) (Ibn Faris, 1976) and (Maqalah Fi Asma' A'ada Al-Ensan) “members of the human”. (Ibn Faris, 1976)

Ibn Faris had authored many books in bulk of science but the content of this research doesn't allow us to mention it.

In order to give a clear image of the development of this controversial issue and the changes on researchers opinions and attitudes, whether they are linguists, philologists or interpreters, I resorted to critical and historical approach in this research. I included scholars and philologists opinions and perspectives who discussed this issue before Ibn Faris. Whereas this issue took place in the era of Ibn Abbas, Al-Shafi'y, Abu Obaidah, Abu Obaid and Al-Tabri. The controversy of this issue did not stopping the fourth century, but continued to this era where narrators and controversialists disagree as early ones disagreed, and used ration Al-(mental) evidenceandarguments as early did.

In order to how Ibn Faris attitude of this issue and what his adding, I compared his opinions with his predecessors and successors. This is to come up with his opinion first, then his arguments to prove his attitude.

Scholars have reached agreement over an crucial issue namely the Arabisedterms as terms used by linguists until the second century of Islam, (second Hijri century) that means words by Arab scholars taken from foreign languages for meanings that are not found in Arabiclanguage. (Ibn Faris, 1976, pp. 235-254)

The Arabised in the Quran is the issues which Ibn Faris addressed in his book (Al-Sahiby). He entitled it with "The speech in language which the Quran was revealed with" (Ibn Faris \& Al-Sahiby, 1963, pp. 57-62).

Ibn Faris narrated on the authority of Abu Obaidah that scholars into disagreed upon the existence of foreign words in Quran, some denied their existence especially linguists, and said that Quran is a miraculous words and every word has to be Arabic the origin or the branch. While other accept the existence of these words in Quran especially philologists. This disagreement continued to our era, whereas our scholars and philologists follow early ones steps.

A third group tried to solve this issue, by bringing these two doctrines into agreement. This group argues that these terms are foreign in origin or alphabetically, but with an Arabic use as philologists said.

Arab used these words in their communication and made changes at phonetic level in order to be similar and identify Arabic characteristics and measures. However, when Quran has been revealed mentioned it them the way Arabs used them, thus, they are from foreign origin but with an Arabic use. In this regard, Abu Obaid said: "the right opinion to me is the doctrine that approves the two attitudes of the two groups, considering that these alphabets are foreign but came to Arabic language and became Arabic through charging their characteristics from foreign into Arabic, thus, who see that they are foreign are right and who see the opposite is also right". (Ibn Faris \& Al-Sahiby, 1963, pp. 60-61)

Every group has their own arguments and evidence, in this context; I will make my attempt to show the evidences of every group according to Ibn Faris classification.

\section{Proponents or Supporting Group}

Philologists and scholars emphasized the presence of Arabised words in the Holy Quran, they argue that few and 
limited foreign words do not affect the Arabism of the Quran, because most words are from Arabic origin (Ibn Faris \& Al-Sahiby, 1963, pp. 60-61). And here are the main evidence for what they argue for:

1) The two Quranic verses: "we have not sent a messenger save in his people's tongue" (Ibrahim/4) and the verse "we have sent you for all mankind and a bearer of good news and carrying warning too (Saba'/28). These two verses are indisputable evidence that Quran has been revealed for all mankind and that the prophet Mohammad is a messenger for all peoples of all tongues. Thus, prophet's people are not restricted to Arabs only, rather to all humanity and races (Al-Tabri, p. 14).

2) Narrations from prophet's honorable companions and followers indicate that Quran includes foreign words, (Al-Tabri, p. 14)

3) for example, they narrated on the authority of

4) Ibn Abbas, that "he was asked Aboutthe meaning of the verse "escaped from Qaswarah" (Al-Modathir/51) He replied, it means the lion in Arabic, Shar in Persian, Arya in Nabataean and Qaswarah in Ethiopian language. (Al-Tabri, p. 14) (As a way of clarification not preference or probability).

5) In addition to their narration on the authority of Sa'eedIbnJubair that he said "Quraish demanded that Quran has to be Arabic or foreign", so the Almighty God revealed that "It is, for those who believe, a guidance and cure.And those who do not believe - in their ears is deafness, and it is upon them blindness". (Al-Tabri, p. 13)

6) On the authority of Abu Maysara "O mountains, repeat [Our] praises with him, and the birds (as well)." (Saba'/10) Sabhi said in Ethiopian tongue (Al-Tabri, p. 14) he also said "Quran has spoken several tongues". (Al-Tabri, p. 14)

7) The Quran includes the early sciences and their stories, thus no surprising that it comprised foreign words according to their perspective: "the wisdom of the presence of these words in the Quran, that it included early and late sciences and their history, thus, the indication to such languages and tongues in order to be comprehensive is indisputable". (Al-Tabri, p. 14)

8) Grammarian emphasize that most Quran's proper nouns are not inflected, such as: Ibrahim, Ismail and Israel (Al-Tabri, p. 14)

9) Foreigners use words that are similar to Arabic words in meaning and pronunciation. (Alsuyooty \& Almuhathab, pp. 61-62)

The most proponent followers of this attitude are as follow: philologist as Abu Obaid mentioned, (24) Ibn Duraid, (25) Abu Hatim Al-Razi, (26) Altha'aliby, (27) Aljawaleeqy, (28) Ibn Aljawzi, (29) Alfakhr Al-Razi, (30) Alsuyooty, (31) and Alshihab Alkhafaji. (32) In this context they mentioned that many words which are said to be foreign as follow:

(Istabraq) is Arabised from Persian, (Abu-Hatim, Al-Razi, \& Al-zinah, p. 136). (Qistas) which is Arabised from Greek, (Altha'aliby \& Fiqh Al-lughah, p. 317). (Dinar) which is Arabised from Persian. (Abu-Hatim, Al-Razi, \& Al-zinah, p. 136). (Al-Tannoor) is Arabised from Persian (IbnQutaibah, Adab Alkateb). (Al-Rabaneyoon) is Arabised from Syriac (Alfakhr Al-Razi \& Al-TafseerAlkabeer, pp. 222-238). (Sundus) is Arabised from Persian (Ibn Abbas). (Al-firdaws) is Arabised from Greek. (Taha /113), (Fussilat/31), and (Al-mishkah) is Arabised from Ethiopian (Al-Shafi'y \& Al-Resalah, p. 47)

\section{Denial Group}

The followers of this attitude have denied the presence of foreign words in the Holy Quran. They say that the alphabets, words, fabrics and structure, and the inability of the most fluent Arab (Quraish) to imitate or come up with a book like it, is an indisputable evidence to the prophet Mohammad-PBH-. If the Quran includes foreign words, God will not defy Arabs to imitate it or to come up with a book like it. The most prominent of this attitude are: Ibn Abbas, Alshafi'y, Abu Obaidah, Al-Tabri, Ibn Faris, Albaqillany, Alqortoby, Alzrkshy and Abdu-AlghaniAlnabulsy.

The proponents of this supported their attitude with mental (rational) arguments, and here are the main elements of their argument:

1- The Quranic verses that indicate that Quran was revealed in Arabic language. (Al-Shafi'y)

The verse: "it is a revelation of the Lord of the faith and trustworthy spirit has brought down upon your heart, (193) that you may be one of the warners, (194) in the plain Arabic language" (195) [Al-Shu'ara].

And the verse: "It is the Quran in Arabic, without any crookedness in order that they may keep from deviation". [Al-Zumar/28] 
And the verse "We have revealed it as an Arabic Quran, so you people may be wise understand" [Joseph/2], and the verse: "Thus we revealed it as an Arabic Law". [Al-Ra'ad/37] and others. (Abu Obaidah)

2- Quran itself denies the presence of any foreign words and emphasizes the Arabism of all words and terms in the verses: "We know indeed that they say, it is a man that teaches him. The tongue of him they wickedly point to is notably foreign, while this is Arabic, pure and clear". [Al-Nahl/103], and the verse: "Had We revealed this as a Quran other than Arabic, they would have said: why are not its verses explained in detail? What! (a book) not in Arabic and (a messenger) an Arab? Say: it's a guide and a healing to those who believe". [Fusselat/44] (Al-Shafi'y)

3- This group denied the first argument of the first group that the word "people"in the verse means prophet's followers regardless of their races and languages. So, they say that the verse means Arabs in general and Quraish in particular, and Arabic language is one of the best man's kind languages.

This attitude measured language to religion.

Since Islam invalidates all previous religions, similarly, Arabic language would be preferable from other languages due for being the language of Prophet Mohammad -PBH-. (Al-Shafi'y)

4- Arabs understood Quran and comprehended all its meanings. They were in no need of other people to interpret some Quranic terms and structure. Thus, if Quran includes foreign words, they indeed will resort to other people to ask their meanings that are out of their mind". (Al-Qortoby \& Al-Jame' Le Ahkam Al-Quran, p. 69)

5- The state of being unfamiliar with standard or old Arabic used in Quran, some Arabs understand just general Arabic and are not familiar with standard Arabic except those who are deep-rooted in Arabic linguistics, because Arabic language cannot be comprehended and mastered except by the prophet: "Those who see the presence of foreign terms of Quran, argue that Quran has standard and general Arabic forms, standard Arabic that some Arabs are not familiar with. This unfamiliarity is due to the depth of Arabic tongue and the plentiness of vocabularies. Thus, it is known for us that such language cannot be wholly comprehended and mastered except by the prophet". (Al-Shafi'y \& Al-Resalah, p. 42)

6- Arabic language is larger than other human languages, (Al-Shafi'y \& Al-Resalah, p. 44) Quran was revealed according to Arabic language ways. Thus, it has general terms that indicate to privacy, in contrast, the private terms that indicate to general. The same term has many meanings (homonymous) and the same meaning has many utterances (synonym), except for figures of speech that scholars and philologists consider the most important sign of Quran miraculous nature.

7- They refuted the attitude of first group and grammarians; e.i most proper nouns in the Quran are foreign, the reason behind being from foreign origin is that their characteristics and measures are not similar to Arabic characteristics and measures such as: Ibrahim, Ishmail, Israel, Marot ... etc. who told you that you comprehended all language characteristics and measures? (if Arabic never used such words in their communication, Allah would not address people in what is out of their knowledge, thus the Quran would not be in a clear Arabic language (Al-Shafi'y \& Al-Resalah, p. 44). Arabic language cannot be wholly comprehended save by the prophet, according to what Alshafi'y said. (Al-Shafi'y \& Al-Resalah, p. 44), while Ahmad Al-Jannaby discussed this argument, which the first group took as an evidence of foreign words presence in the holy Quran. In addition, he invalidated their opinion and grammarian's argument in this researchentitled (originating the Arabism word Ibrahim) in Al-ddad magazine. (Ibn Abbas \& Al-Lughat Fi Al-Quran, p. 16)

8- The second group provided a new linguistic theory in order to refute the saying (be similar to Arabic language). (Abu Obaidah, Majaz Al-Quran, pp. 17-18.) Just as approving world languages similarity, if there is any verbal similarity between peoples who are varied in area and language, it would be due to learning first or being subordinated. The absence of these two reasons causes to approve similarity between human languages. (Al-Tabri, Jame' Al-Bayan, pp. 15-16). Ibn Abbas followed by Alshafi'y refuses similarity theory "Quran includes just the Arabic words". (Al-Nabulsi \& Abdel-Ghani)

Abu Obaidah followed both Ibn Abbas and Alshafi'y who said: "two terms may agree and be close to each other in the meaning, although one of them is Arabic and the other is Persian such as term (Istabraq) which means the thick part of brocade". (Al-Nabulsi \& Abdel-Ghani)

Also Al-Tabri "we never denied that words of different language and races may be similar to each other in the meaning. The right thing for us to be called Arabic foreign and if there is any similarity between words of different tongue, this would mean that one of these two words has to be the origin". (Al-Nabulsi \& Abdel-Ghani) 
9- Denials depended on a historical evidence to prove their theory(Ibn Abbas, Allughat fi Al-Quran, p16)Arabs were divided into two groups: Original Arabs who used to speak old Arabic language (ya'rub bin Qahtan), and ArabisedArab who used to speak (Ismail) tongue (Al-Nabulsi \& Tashreef Al-Taghreeb, pp. 169-170).

This evidence is based on the fact that foreign taken words form (standard or original Arabic) old Arabic and made their change whether adding alphabets or omitting them. When the Quran has been revealed, it mentioned these words or terms in its old form, so people thought it to be foreign. Due to the Arab's use of them, the fact is that Arabised words dated back to its historical fact, than making then suitable with sounds Arabic taste.

10- Arabic language is a language created by God (Ibn Faris, Al-Sahiby, p60-61), the origin of all languages on the face of earth, thus, any language has to be a branch of it.

The all revelations were through gabriel in Arabic language to prophets. However, the messenger gets his message across in his people language. (Al-Qortoby \& Al-Jame' Le-Ahkam Al-Quran, pp. 68-69.)

They depended upon evidences told by prophet's companies, the narration of SaeedIbnAl-Mosayyab on the authority of Abu Hurairah that the messenger -PBH- said:"God did not send Gabriel to his prophets save in Arabic revelation, then the prophet gets the message across in their people tongue". Al-Tabrani in (Al-Moajam Al-Awsat) said: sound reliable Hadith and its narrators are most reliable.

According to Abu Hurairah that the prophet Mohammad said:"I speak Arabic, Quran speaks Arabic, heaven's people speak Arabic as well"included in Al-Tabarani book (Al-Awsat) who said reliable hadith. (Al-Zarkashi)

\section{Intermediate Group}

An intermediate attitude has appeared when this matter occurred. This group aimed at bringing the two other contradicting perspectives into an agreement. Therefore, they said that the words philologists considered to be foreign in origin but with an Arabic use. Thus, they satisfy the two contradicting groups, through considering them foreign which satisfies supporting team, and through saying that they are with an Arabic use which satisfies the other group. This group was led by Abu-Obaid Al-Qasem Bin Sallam who stated: "As for which I consider to be truth-God knows best- is to approve the attitudes of two groups, on the grounds that these words are foreign in origin, as philologist see; but they became Arabic in use and converted them from foreign utterances into Arabic ones, Then became a part of Arabic language, When Quran has been revealed, these words were part of Arabics' use. Thus, those who see them foreign are right, and who see them Arabic are also right". (Ibn Faris \& Al-Sahiby, p. 59).

Following Abu-Obaid's opinion, IbnAtiya said: “As a matter of fact, these words or terms are foreign in origin, but Arabs used them in their language and Arabised them, this, they are Arabic from this aspect.

Original Arabs whom the Quran has been revealed in their language, had a social relations with people with different tongues and languages in their travels and trades such as: Trade and travels of Quraish, travels of Bin Abu Amro to sham, travels of Omar Bin Al-khattab, travels Amro Bin Al-Aas to Ethiopia, travels of Al-A'sha to Al-Haira and this friendshipto their Christians.

It this communication with other societies of other languages, many words have been brought to Arab's tongue with little changes at alphabetical level, in order to suit their tongue in poetry's use. Thus, these foreign words took the same and true course as Arabic words.

When Arabs fail to know them in Quran, this will be due to ignorance of others' language, just as what Ibn Abbas faced when he failed to know the meaning of (Fater) word ... etc. (Ibn Faris \& Al-Sahiby, 1963, p59 )

Following the Above scholars, Abu Al-Ma'ali who supported this attitude with the same Quranic verse that the first team provides as an evidence, the almighty says: "We have not sent a messenger save with his people's tongue" (Ibrahim/4) (Ibn Faris \& Al-Sahiby, 1963, p. 59). Ibn Faris in critical review:

If we examined what Ibn Faris included in his book regarding this issue, looked for what the new he has given and compared his view with that predecessors and successors said, we would notice that he just provided few opinions and views.

Ibn Faris denied the presence of forein words in Quran, he has supported his attitude with the following evidences:

(1) Quranic verses: As for being the Holy Quran revealed just in Arabic words, the almighty says: "We have revealed the Quran in Arabic language" (Zukhruf/3), "We have not sent a messenger save in his people's tongue" (Ibrahim/4) and says: "In a clear Arabic tongue" (Al-Shu'ra/195) (Ibn Faris \& Al-Sahiby,1963, p. 59) 
(2) Ibn Abbas saying: "Allah sent his messengers in their people's tongue, and Ibn Faris mohammad-pbh-is the messenger who Allah sent in Arab's tongue". (Ibn Faris \& Al-Sahiby, 1963, p. 59)

(3) Considering Abu Obaidah's attitude (Ibn Faris \& Al-Sahiby, 1963, p. 61) who said: "The Holy Quran is wholly included with Arabic words, but if there is any linguistic similarity between two languages, it would be due to linguistic alignment between human language". (Ibn Faris \& Al-Sahiby, 1963, p. 62 )

1- Ibn Faris did not add that much to what Al-Shafi'y and Abu Obaidah said, yet he used their evidence and arguments. Here is what Ibn Faris added to their attitudes.

His criticism to the evidence that Abu Obaid based on his intermediate attitude for fear of accusing philologist with the ignorance due to supporting the presence of foreign words in the Holy Quran, Abu Obaid said in this regard:

"We interpreted this in order to consider not philologist as ignorant, and not accusing them for being dealt with Allah's revelation in a way God never wanted, being knowing best aboutQuran and regarding it as great." (Abu Obaidah, Majaz Al-Quran)

(4) replied on this argument, that it is apparently invalid, "not all who disagree with someone's saying can be considered as ignorant, because head predecessors disagreed with each other in Quran's interpretation, and successors followed their disagreement, whereas some accepted a view while other accepted other view according to their conclusive opinion." (Ibn Faris \& Al-Sahiby, 1963, p. 62).

We can say about Ibn Faris' ability to ruin the basis intermediate group depended on in their attitude: there is no intermediate group, but conciliatory group to the first group, scholars and philologists are divided into two groups:

Denials who deny the presence of foreign words in Quran, and proponents who support the presence of these words. Because foreign origins of these words are impossible to be out of fluent linguists' knowledge, like: Al-Shafi'y, Abu Obaidah, Ibn Faris Al-Baqillany. (Ibn Faris \& Al-Sahiby, 1963, p. 62)

2- The interpretation of Ibn Faris for Abu-Obaidah's phrase: "those who claim the existence of foreign words, they made a big mistake". (Ibn Faris \& Al-Sahiby, 1963, p. 6)

Also said: "if anyone says: what does Abu Obaidah mean when he said made a big mistake? The answer must be that he committed a great mistake because if the Quran includes other languages people will say: Arabs were unable to come up with a book like it because if being revealed in other languages that they do not know". (Ibn Faris \& Al-Sahiby, 1963, p. 62)

3- His refusal to the permission of reciting Quran in prayer in Persian language, he said:"rather it is more proper to read interpretation books in prayer. Due for being in Arabic, and Arabic is a miraculous language. As for reciting Quran in Persian language is out of reason and logic, due for being lack of miraculous characteristics: "if so, there is no evidence for those who give the permission to recite translated Quran in prayer, because translation will never be miraculous due for being human-made translation. However, God ordered to recite his miraculous revelation in Arabic, the language it was to revealed in prayer." (Al-Shafi'y \& Al-Resaleh, pp. 44-45)

Those who look into what Ibn Faris adding will realize how he strongly denies the existence of foreign words in the Holy Quran.

If we want to conclude Ibn Faris mistakes and flaws, we will notice that he ignored elaborating on two main topics, which are:

\section{1- Alignment theory:}

Ibn Faris did not deal with the concept of linguistic alignment and did not express if he supports or denies it, even though the one who looks into his book, finds that Ibn Faris accepted this theory according to what he said: "the truth is what Abu Obaidah said".

If the word was said first by Ibn Abbas on the authority of Ibn Hasnoon, followed by Al-Shafi'y, Abu Obaidah, Al-Tabri. Ibn Abbas alignment word would be added by IbnHasnoon the reciter, in addition, it would be verbal alignment according to Ibn Abbas and Al-Shafi'y, in sense organs which have phonetic characteristics in ears, e.g. animal sounds, languages may resemble each other in the sound of the cat (meow), sounds of nature such as thunder, water and wind. They may call thunder sound (Dof, Dov, Dob...) and sounds caused by knocking the door by hand, this what is called (Duk, Daq, Nuq, Nuk).

However, this concept has developed according to civilization and linguistics for Abu Obaidah and Al-Tabri. While these two scholars accepted nouns and terms alignment in meaning and verbally. 
Do not believe this opinion reasonably, because it is hard to find two nations who agreed to give a term and noun for a special term.

I really have no idea why Abu Obaidah and Al-Tabri used such ambiguous of the Holy Quran, from structure aspect and meaning, thus, I find this term unimportant and unnecessary due for giving the thought that Quran includes Persian words: ("Sajeel"is a Persian term along with Sauak and Kul which means stones and clay"). (Ibn Faris \& Al-Sahiby, p. 59). Which Abu Obaidah proved to be Arabic when he said: "Sajeel means the one who is strong and tough (Ibn Faris \& Al-Sahiby, 1963, p. 59)

The reason behind making me deny this opinion and attitude and describe it with weakness is for being two-edged sword, which can be interpreted in favor of the Arabism of the Quran. In addition, it can be an evidence to the presence of Arabised words or terms in the Holy Quran. IbnAtiyah refused to accept alignment theory when he said: "what Al-Tabri argued for that the two languages have agreed in the word is not probable, rather one of them are the origin, while the other is a branch, however, we don't pay for the permissibility of agreement the less and the odd." (Ibn Abbas \& Al-lughat fi Al-Quran, p. 16.)

2- Ibn Abbas attitude: Ibn Faris narrated a saying of Ibn Abbas that proves his perspective of the absence of foreign words in the Quran because the Quran is Arabic and revealed in Arabic. (Abu Obaid \& lughat Al-Qba'el, p. 41)

Ibn Faris also narrated a saying of Abu Obaid proving that Ibn Abbas accepted the presence of foreign words in the Quran. (Al-Tabri \& Jame' Al-Bayan, p. 13.)

These both sayings contradict each other Ibn Faris did not pay attention to and show if Ibn Abbas supports the first group or the other.

Whereas narrations of Ibn Abbas contradicted each other, some denies the presence of foreign words in Quran, while others see the opposite. The most important narrations of denials that such as:IbnHasnoon and Abu ObaidAl-Qasim, in their books: (languagesin Quran) (Al-Tabri \& Jame' Al-Bayan, p. 13.) (and tribe's languages included in Quran). (Al-Shafi'y \& Al-Resaleh, p. 42)

In regard to the most famous book included narrations that prove Ibn Abbas faith of their presence in Quran is (Al-Tabri's book). On the authority of SaeedIbnJubair that Ibn Abbas said In regard to the verse: "the Nashe'a of night" (Almuzzammil/6) Indeed, the hours of the night are more effective for concurrence [of heart and tongue] and more suitable for words." the word "Nashe'a"means awaking in Ethiopian tongue (Al-Suyooty, (died911H). Al-Etqan) and other words. (Al-Aamedi \& Al-Ihkam, p. 51.)

Those: Abu Obaid, IbnHasnoon and Al-Tabri narrated on their authority are most reliable and cannot even pay doubt for them.

But personally prefer Abu Obaid and IbnHasnoon narration because they were contemporaneous with Ibn Abbas, as well as we do not know people who Ibn Abbas interpreted Quran for them. These people may be from Yemen who their language mixed with Ethiopian language. Ethiopian language used many words from Yemeni language, thus, these words became very important pillars in Ethiopian language, Ibn Abbas may interpret Quran for Yemeni people using Ethiopian words, which were in the past Arabic Yemeni words. These people may be from Ethiopia, Greece or Persia. We know that Ibn Abbas is skillful scholar of our people, but he cannot be well versed in language secrets, dialects, past words and present words altogether. Because Arabic language is the sum of the sciences that Arabs cherish, even if they were different at quantity level.

Some Arabs know much of language, while others' knowledge of language is little. So Ibn Abbas may have missed what tribe ascribed these words are ascribed, because Arabic language is not be well-known save by the prophet. (Al-Aamedi, \& Al-Ihkam, p. 51.) This is not strange because Ibn Abbas did not recognize the meaning of "Fatir"and "Fatih". (Al-Aamedi \& Al-Ihkam, p. 51.)

"This is why Ibn Abbas said I do not know what is the meaning of "Fatir" in the verse "[Allah] praise is [due] to Allah, Creator of the heavens and the earth" [Fatir/1] Until I heard an Arabic woman says the word "fatartoh"means I brought something into existence." (Al-Suyooty \& Al-Muhathab, p. 66)

Just as when Omar Bin Al-Khattab did not know the meaning of "Abba", when wondering after reading the verse of "And fruit and abba" (absa/31), what is "abba". (The Arabic Tongue Magazine,1970) The word that Al-Suyooty explains in his book (Al-Mohathab) on the authority of Shedlah in "Burhan":"Abba means grass in Morrocan language". (The Arabic Tongue Magazine)

The revision Al-MuhathabAl-TehamiAl-RajiAl-Hashemi, supported him on that, which means that it is Arabaized, however, he pointed out that it is Arabaized from Aramic language not Moroccan. (Anastas Karmali) 
Furthermore, Abdul HaqFadel proved in his essay Dakheel Am Atheel, which means"Arabised or original Arabic" (Al-Hilal house, cairo) the authentic Arabic of this term, which means "Al-Kal'a"ormedow or whatever plants grow on earth-according to dictionary definition. While in Arabic, it comes as "ebo"which means fruit and athel or father "ab"whichArabs refer by it. "The grass which grows on earth after the rain fall or it means the meaning of water which transformed into grass that grows by water. It is clear that Arabic did not borrow the term from Aramaic, in contrast, Arabic referred by this term to every plant grows on earth-grass or vegetables"then it focused on the Aramaic by the term of fruit. (Edition 1)

\section{The Opinion of Neo-Classic Scholars}

The neo scholars have taken stand towards this issue, some of them endorses the presence of foreign words in the Holy Quran such as priest Anstas Al-Karmali in his book (The evolution of Arabic language its growth and getting old), (Arabic house for Bustani, Cairo, 1965 A.C.) also Georgy Zaydan in his book (Arabic is an animate), (Iraq Scientific forum press 1988 A.C.) Erfan Abu hamad in his book, (foreign terms in Arabic), (Alddad Magazing-Iraq) and Tobia Al-Anasi in his book (The Persians interpretation of the Arabic internal terms in addition to mentioning their origin laterally). (Complex of languge Arabic Magazine)

In the other hand, some of them denied the presence of the foreign words in the holy Quran such as: NoriHammodi Al-Qaisy in his article (Like this Persians manifested the Quranic language), Dr.KamilHasan Al-Baseer in his article: (linguistic searching from the fields of science to the biased hypocrisy), andDr.AhmadNasief Al-jannaby in his article (fabricated talk), theses three previous articles were collected in a book named: "Enna Anzalnaho Qur'ananA rabyan" which means: (We revealed the Quran in Arabic language) (Nour Hammodi Al-Qaisy) also Dr. Ahmadmatloob in his article (pathways tucking populist in Arabic languge) (Al-Jawaleeqy) who have denied ways of people's illegal trial in Arabic language those who denied any word in Quran be characterized by being a foreign word.

This is clearly manifested in their response to Mahdi Mohaqeqwho wrote an article in title (The effect of Persian language on the Arabic language during the prophet's era). This article contains the focus of the presence of Arabised in the Arabic language from the time it was evolved.

Mahdi Mohaqeq used some terms as a prove in the poetry of Al-Aasha, the main foundation which the research was built upon is that: the presence of the Arabised in the Quran and the Hadith and in away Abu Hanifa allowed prayers to be in Persian.

Even though, those people came up with evidence and qualitative and logical argument that proves the invalidity of what Mohaqeq has alleged, the most important of these arguments:

They invalidated the evidence that Mohaqeq based on in his essay. They said that Persian language that Mohaqeq alleges that it has an effect on Arabic language, Quran language and Al-Hadith. Rather it is a modern language id it is as compared to the arising of Islam and the revelation while those proved that it is a recent language. When it appeared after two centuries from sending the messenger Mohammad-PBH-to human (7 A.C), which was called (Islamic Persian). The prevailing language in prophet Mohammad-PBH- era was the old Persian language (Fahlawiya) which extinct, so it cannot affect Quran language and Hadith before its appearance, be circulated are to be written in scientific or literary publications. (Abu Obaidah \& Majaz Al-Quran)

Moreover, the existence of foreign words in the Quran was denied by Ahmad Mohammad Shakir, who said: "they see that this Quran, which Allah bestowed Arabs with, is Arabic, and it is unreasonable to include foreign word”. (Al-Qortoby \& Al-Jame’ Le Ahkam Al-Quran, p. 69.)

The attitudes of denial, proponents and intermediate group were revealed and discussed whether those groups before or after Ibn Faris period.

The attitude which I am convinced to follow is what Al-Shafi'y, Ibn Faris, Al-Baqillany, Al-Nabulsy, and Al-Jannaby argue for. Due to the validity and the strength of their evidences and arguments. In addition, I do not know for what reason our scholars pay so much attention to these few words and make such big deal-out of nothing.

Quran itself suffices them, when it includes in its verses the denial-of foreign terms presence eleventh times, and the quran denied itself that foreign oroutlandish (non Arabic) two times. Thus any word in the Quran has to be Arabic in origin; It may be Arabic then used by Ethiopians, then Quran included it to prove its Arabic origin.

\section{Conclusion}

There have been Crucial issues which have kept Islamic thought and jurisprudence busy since the advent of Islam. One of these issues which kept authors philosophers, Linguists, jurprudents and modern day scholars in 
constant debate for the purpose of finding what is logic and acceptable according to Islamic Faith, and what is not namely, is the terminology of the Quran where as the Quran asserts that all its terms and words are pure Arabic; however some authors use in this argument the word. "except" some words are Arabised. This claim contradicts the sayings of the Quran "The language of the Quran is Arabic". This means that the terms of the Quran are selected and understood by people live in the Arab peninsula who are Arabs. Arabs have been proud of their language and other peoples were taken words from Arabic not vise versa.

Thus the Quran is revealed in Arabic. As the case with every dynamic and lively issue, some authors claim that Quran includes some Arabised words. This group relied on the writings of Ibn Abbas which, have analyzed to find out that all groups relied upon him in her clam.

Have used the writings of Ibn Faris who has strong and convinced argument that the Quran is revealed in Arabic. With diligent endeavour and research through history books and language, philology publication from old, I could prove that the opposing group and the intermediate one are wrong, while the supporter of the argument that Quran is Arabic, are right.

\section{References}

Abd el Haqq Fadel, Dakheel Um Atheel, The Arabic Tongue Magazine, volume 7, section 1, 1970 A.C, and after.

Abu Haian Al-Andalusi, A thir Al-dein Abu Haian Mohammad bin Yousif Ali Maw'ed et al., edition1, scientific books house-Beirut-Lebanon.

Abu Htim Al-Razi, Ahmad bin Hamdan (322H). Al-Zena fi Al-Kalimat Al-Islamia Al-Arabia, objected in his book usul: Hussain bi Faid Allah Al-Hamthani Al-ya'bri Al-Harzi, edition 2, Arabic book house. Egypt-Al-qahira 1957 A.C.

Abu Obaid Al-Qasim Bin Salam Al-Harawi (224H). Lughat Al-Qaba'el Al-Wareda Fi Al-quran Al-Kareem, revised by Abdel Hameed Al-Sayed Talab, Kuwait,1984 A.C.

Abu Obaida, Mu'ammar Bin Al-Muthanna Al-Tamimi (209H). Majaz Al-Quran, reviewed and objected by Mohammad fu'ad Sizkeen, edition 1, Mohammad Sami Ameen Al-khanji Al-katbi, Egypt, 1954 A.C.

Ahmad Matloub, Aldad Magazing-Iraq, section 2, 1989 A.C.

Ahmad Nasif Al-JannAby, fabricated Hadith “Inna Anzalnahu Qura'anan Arabia”The Iraqi form printing house 1988 A.C.

Ahmad Nasif AljannAby, ta'sil Urobat lafthat Ibrahim. Al-dad Magazine, section 2, 1989 A.C.Alqahira, 1971.

Al-Aamedi, Saif Al-dein Abu Al-hassan Ali bin Abu Ali bin Mohammad (631H). (Al-ihkam fe usoul Al-ahkam) review: Abd Al-Razaq Afifi, edition 1, Al-Nour for publication and pakaing. Al-Riad institution 51387.

Al-Bagdadi, Al-Hafith Mohib Al-dein bin aAl-najar (630H). Al-Mustafad Min thail Tarikh Bagdad. Revised by Mohammad Mawload Khalaf, Bashar Awad Ma'roof, edition 1, Al-Risala institution Bairut-Lebanon 1986 A.C.

Al-bakherzi, Nour Aldien Abu Al-Hassan Ali bin Al-Hassan (467H). Dumiat Alqasr wa Asrat Ahl Al-Asr. Revised by: Sami Makki Al-Aani edition 2, Bagdad University which helped in publishing, Al-Nu'man printing house, Al-Najaf Alashraf.

Al-Baqilani, Abu Baker Mahammad bin Al-Taib (403H). Eijaz Al-Qura'an. Revised by Al-said Ahmad Saqr, edition 3, dar Al-maa'rif, Egypt-Alqhira 1971 A.C.

Al-Fairuz Abady, Majd Addein Abu Al-Tahir Mohammad Bin Yaqoub (799H). Al-Qamous Al-Muheet, Al-Hadith house, Cairo.

Al-Fakher Al-Razi, Mohammad Bin Omar Bin Al-Husein (604H). Al-Tafseer Al-Kabeer, Ehya' Al-Turath Al-Arabi house, Beirut, Lebanon.

Al-jawaliqi, Abu Mansour Mawhoob bin Ahmad bin Mohammad bin Al-khudair (died in 540H). Al-Mou'rab min Al-kalam Al-Aajami Ala Hurouf Al-Mou'ajam. Revised and explained by: Ahmad Mohammad Shakir copied Again in Al-Uvist in Tahran, 1966 A.C.

Al-Khalil bin Ahmad Al-Farahidi abu Abd Arahman (170H). Al-Ain, revised by: Mahdi Al-Makhzumi and Ibrahim Al-samere, edition 2, Al-HilAl-house and libarary, and The house of public culturAl-affairs 1986 A.C.

Al-Nabulsi Abdel Ghani Al-Nabulsi (1143H). Tashreef Al-Taghreeb Fi Tanzeeh Al-Qura'an A'an Al-Ta'reeb, revised by: Abdallah Al-JAbuuri, Adab Al-Mustansereyya magazine, no.13, 1986 A.C. 
Al-Qufdi, JamAl-El deen Abu Al-Hassan Ali Bin Yousef (died 646H). Anba Al-Rowah Al-Anba Al-Nuhah, editor Abu Al-Fadl Ibrahim, $1^{\text {st }}$ Ed, Egyptian book store, cairo, Egypt 1950.

Al-Qurdubi, Abu Abdullah Mohammad (died 671H). Al-Jame' for Ahkam Al-Qura'an $2^{\text {nd }}$ ed. Egyptian book store Egypt 1952.

Al-Shaf'I, Mohammad bin Idris (204H). Al-Resala, explained and revised by Ahmad Mohammad Shakir, edition 1, Mustafa Al-bAbu Al-HalAbu and his sons library and publishing house, 1940 A.C.

Al-Suyooty, Abd Al-Rahman JalAl-Al-Dein (911H). Al-muhathab fema Waqa'a Fi Al-Qura'an min Al-MuArab. Revised by: El tehami Al-Raji Al-Hashimi, typed under Supervsed by the joining comitee for spreading Islamic heredge between government of Moroccan Kingdom and government of United Arab Emirates.

Al-Suyooty, Abd Al-rahman Jall Al-Dein (911H). Al-Etqan Fi Olum Al-Qura'an, Knowledge ho9useBeirut-Lebanon.

Al-tha'alibi, Abu Mansour Abd Al-malik bin Malohammad Al-NisAburi (429H). Fiqh Al-Lugha wa sir Al-Arabia, FinAl-edition. Revised by Mustafa Al-Saqa, Ebrahim Al-Aybari, and Abd Al-Hafeeth ShalAbu, Mustafa Al-BAbu Al-HalAbu and his sons liberary and company, Egypt 1972 A.C.

Al-thahAbu, Shams Al-dien Abu Abd Allah Mohammad bin Ahmad bin Uthman (748H). Sair Aa'lam Al-Nubala'a. Revised by Shu'aib Al-Aranau'ut and Mohammad Nai'm Al-Erqsus, edition 1 Al-Risala institution, Beirut-Lebanon 1983 A.C.

Al-Tubri, Abu Jafar Mohammad Bin Jareer (310H). Jame' Al-Bayan And Ta'weel A'ayat Al-Qua'an, revised by Mahmoud Mohammad Shakir and Ahamad Mohammad Shakir, Al-Ma'aref house, Egypt, edition 2, Dar Al-Fikr Press.

Al-Zamakhrashi, Al-Imam Mahmoud bin Omar Al- Zamakhrashi (538H). The Interpretation of Al-Kashaf for revelation ambiguities and Arabic Oyon Al-Aqaweel, Al-Arabi- Beirut 1987 A.C.

Al-Zarkali, Khair Al-Dein, Al-A'lam, edition 9, house of scince for millious, Beirut-Lebanon, 1990 A.C.

Al-Zarkashi, Badr Al-dein Mohammad bin Adbullah (794H). Al-Burhan Fi Ulum Al-Qura'an,, revised by: mohammad Abu Al-FAl-Ibrahim, edition 1, Arabic books revival, Issa AlbAbu Al-HalAbu and partners Cairo house, Egypt, 1957 A.C.

Al-Zubaid, Al-Said Mohammad Murtada Al-Hussaini (1205H). Taj Al-Arus Min Jawaher Al-Qamous. Revised by Abd Al-Sattar Ahmad Faraj, Ministry of Guidnce and information. Kuwait 1965 A.C.

Arfan Abu Hamad, Alfath Ajnabeyya Fi Al-Lugha Al-Arabeyya, edition 1, Al-Mashreq house for translation, publication and printing Shifa Amr, 1983 A.C.

Ebrahim Anis, dalalat Al-Alfath, deithion 2, the Egyption Anjlo libarary, Al-qahira 1963 A.C.

Gourji Zaidan, Al-Falasfa Al-Lughaweia, edition 1, Al-jaeel for puplication and distribution, Lina Aashour Beirut, Lebanon 1982 A.C.

Gourji Zaidan, Al-Lugha Al-Arabia Ka'en Hai, Al-HilAl-house, Al-qahira.

Ibin Kather, Abu Al-Feda' Isma'el Bin Kather Al-Demashke (Died 744H). Mukhtasar Tafser Iben Kather, Revised by Muhammad Ali Al-SAbune, Edition 7, Dar Al-Qouran Al-Kareem, Bairut-Libanon, 1981.

Ibn Abbas, Bbdullah Bin Abbas Bin Bdel Muttaleb (68H). Al-Lugha Fi Al-quran,Rewayat Ibn Hasnoon Bi Isnadiha Ila Ibn Abbas, revised by Salah Addien Al-Munjed, edition2, The New Book House, Beirut, Lebanon, 1972 A.C.

Ibn Al-jawzi, Abu Al-Faraj Abd Al-rahman bin Ali (597H). Fonoon Al-Afanan fe Oyon Olum Al-Qur'an. Revised by Hassan dei'a Al-dein Atr, edition 1, Al-bashair Islamic house, Beirut_Lebanon 1987 A.C.

Ibn Durid, Abu Baker Mohammad bin Al-Hassan Al-Azadi Al-Basari (321H). Al-jamhara (bab Ma takallamat beh Al-Arab min kalam Al-Ajam Hatta Sar Kallugha) new edition, edition 1, Al-Muthanna Libarary, Bagdad (1345H).

Ibn Farhoun, Ibraaahim Bin Ali Bin Mohammad Al-Ya'muri, Al-Deebaj Al-Mudahab,, editionl, Al-Sa'adeh Press, Egypt (1329H).

Ibn Faris Ahmad Bin Faris Bin Zakareyya Al-Razi Al-Qazwini (395H). Tamam Faseeh Al-Kalam, Mustafa Jawad and Josheph Jocub Mascuni, Al-Jumhureyyahouse, Baghdad, 1963 A.C.

Ibn Faris, Abmad Bin Faris Bin Zakareya Al-Qazwini (395 H). Mutakhayar Al-Alfath, revised by Al-HilAl-Naji, 
Rebat, Morrocan Kingdom.

Ibn Faris, Ahmad Bin Faris Bin Zakareya Al-Razy Al-Qazwini (395H). Fi Asma' A'ada' Al-Insan, revised by FaaisAl-Dabdoub, Al-Majma' Al-Elmi magazine, Demuscus.

Ibn Faris, Ahmad Bin Faris Bin Zakareyya Al-Razi Al-Qazwini (395H). Al-Sahiby Fi Feqh Al-Lugha waa Sonan Al-Arab Fi Kalameha: Mustafa Al-Shweimy, Dr. Badran instifution for printing, Beirut, Lebanon, 1963.

Ibn Faris, Ahmad Bin Faris Bin Zakareyya Al-Razy Al-Qazweeny (395H). Awjaz Al-Sayr Li Khayr Al-Bashar, revised by HilAl-Naji, taken from Al-Mawrid Baghdad magazine, volume 2, no 4, 1973 A.C.

Ibn Faris, Ahmad Bin Faris BinZahareyya Al-Razy Al-Qazwini (395H). Futya Faqih Al-Arab, revised by Hussein Ali Mahfuth, Al-Majma' Al-Elmi magazine in Demuscus, volume 33, section 3+4, 1958.

Ibn Faris, Ahmad Bin Zakareya Al-Razy Al-Qazwini (395H). Al-Maqayees, Revised by AbdelSalam Haroon, edition 1, Al-Jeel house, Beirut-Lebanon, 1991.

Ibn jenni, Abu Al-fath Uthman bin jenni Al-mousli (392 H). Al-Muhtasib fe shawth Al-Qira'at. Revesed by: Ali Al-najd, Nasif and Abd Al-Halim Al-Najar and Abd Al-Fatah Esm'il ShalAbu, the higher council for Islmic Affairs, The committee for Islamic Heritage revival, Al-qahira 1966 A.C.

Ibn Manthor, Abu Al-Fadel JamAl-Al-Deen Muhammad Bin Mkram (711H). Lesan Al-A'rab Dar Sader, Dar Bairut-Llibanon,1955,1956,1968.

Ibn Qutaibah, Abu Mohammad Abdallah Bin Muslim Al-daynouri (279H). Adab Al-Kitab, revised by Mohammad Muhyee Addein Abdel Hameed, edition 4, the Grand commerciAl-publisher, Egypt, 1963.

Ibrahim Anis, Linguistis voices, the Egyption Anjlo Egypt- Alqahira 1987 A.C.

Kamel Hassan Al-Baseer, Al-Laghwi reserve from science to Bros "we revealed it Arab Quran,Iraqi Scientific forum pres 1988.

Mahde Muhakak, Athar Al-Fareseah Fe Al-Logha Al-Arbeia Fe 'Ahd Al-Rasol Sla Allah 'Aleh W Slam, Majma' Al-Lugha Al-Arabeia Magazine, Demashik.

Noure Hamoudah Al-Qaisi, Hakatha Eatajna Al-Fours 'Ala Loughat Al-Qouran "Ena Anzlnaho Qouranan 'Arabeian”, The Iraq Scientific Housing, 1988.

Shihab Al-Dein Al-Khafaji, Mahmoud or Ahmad Al-Masri (1069H). Shifa'a Al-ghalil Fima Fi Kalam Al-Arab Min Al-Aakhil, reviewed and revised by Mohammad Abde Mon'em Khufaji, edition1, commerciAl-Al-Haram Al-Hussainy Al-kulbra library, Egypt, 1952 A.C.

Tubia Al-Ansi, Tafseer Al-Alfath Al-Dakheilah Fi Al-Lugha Al-Arabia Ma' Thikr Aselha Bi Huroufehi, Dar Al-Arab Lil Bustani, Cairo, 1965 A.C.

Yaqot Al-Hamayi, Abu Ubd Allah Al-Romi Al-Hamawi. (D 626H). Mu'jam Al-Odaba', Revised By: Ehsan Abas, Dar Al-Gharb Al-Eslame, Edition 1, Bairut-Libanon, 1993.

\section{Copyrights}

Copyright for this article is retained by the author(s), with first publication rights granted to the journal.

This is an open-access article distributed under the terms and conditions of the Creative Commons Attribution license (http://creativecommons.org/licenses/by/3.0/). 